\title{
A FUNÇÃO SOCIOAMBIENTAL DA PROPRIEDADE: UMA ANÁLISE HISTÓRICO-JURÍDICA DA RESPONSABILIDADE DO PROPRIETÁRIO
}

\section{THE ROLE OF ENVIRONMENTAL PROPERTY: A HISTORICAL AND LEGAL ANALYSIS OF THE OWNER'S RESPONSIBILITY}

\author{
${ }^{1}$ Gabriella de Castro Vieira \\ ${ }^{2}$ Ecio Nacur Rezende
}

\section{RESUMO}

Este artigo demonstrará através de uma pesquisa bibliográfica e jurisprudencial, a evolução do Direito de Propriedade, suas configurações e a função socioambiental, mediante uma nova leitura da Constituição Brasileira de 1988. O propósito é ressaltar a importância da efetivação das normas ambientais, sobretudo o controle social de utilização positiva das funções da propriedade, objetivando responder o problema da validade do princípio socioambiental no ordenamento jurídico pátrio, bem como a responsabilidade do proprietário frente a esta questão. Para tanto, utilizar-se-á o método jurídico-teórico do raciocínio dedutivo na análise de doutrinas, jurisprudências e artigos científicos.

Palavras-chave: Propriedade, Função socioambiental, Controle, Utilização positiva, Coletividade, Responsabilidade

\begin{abstract}
This article demonstrates through a bibliographic and jurisprudential research, the development of the Property Law, settings and environmental function through new reading of the Brazilian Constitution of 1988. The purpose is to highlight the importance of effective environmental standards, particularly control social positive use of the functions of the property, in order to answer the question of the validity of the environmental principle in the Brazilian legal system, as well as the responsibility of the owner in front of this issue. This shall be used, the legal-theoretical method of deductive reasoning in the analysis of doctrines, jurisprudence and scientific articles.
\end{abstract}

Keywords: Property, social and environmental role, Control, Positive use, Community, Responsibility

1 Mestranda em Direito Ambiental e Desenvolvimento Sustentávelna Escola Superior Dom Helder Câmara. Advogada. Escola Superior Dom Helder Câmara - ESDHC, Minas Gerais. Brasil

E-mail: gabivieirabh@hotmail.com

2 Mestrado em Direito pela Pontifícia Universidade Católica de Minas Gerais. Professor do Programa de Pós graduação em Direito da Escola Superior Dom Helder Câmara. Escola Superior Dom Helder Câmara - ESDHC, Minas Gerais. Brasil - E-mail: elcionrezende@yahoo.com.br 


\section{INTRODUÇÃO}

A origem da propriedade remonta às sociedades primitivas e, ao longo da transformação da humanidade contraiu diversas características, até culminar na configuração atual com a feição de função socioambiental, conforme estabelece a Constituição da República Federativa do Brasil de 1988 e o Código Civil brasileiro.

Com a evolução da sociedade o conceito de propriedade avançou, perdendo o seu caráter absoluto, que implicava em exercício de um puro direito subjetivo do proprietário de dispor e utilizar do seu bem de acordo com a livre vontade, atendendo apenas aos seus desejos, sem considerar o interesse da coletividade.

Nesse contexto, o presente trabalho aborda os contornos históricos da propriedade, com análise da sua origem e significados. Para tanto, discorrer-se-á sobre a evolução do conceito de propriedade desde os primórdios até a atualidade, com ênfase na legislação brasileira.

Após o exame do desenvolvimento e da concepção da propriedade, será tratada a sua atual formulação, qual seja a sua função socioambiental. Objetiva-se demonstrar que tal caracterização visa combater a prática abusiva e excessiva do direito do proprietário de usufruir e desfrutar do seu bem, mediante a imposição de limites internos e positivos ao seu comportamento.

Assim, será exposto o tratamento que o ordenamento jurídico brasileiro vigente dispensa à propriedade, na intenção de conter os abusos praticados diante do seu exercício, especificamente a Constituição da República, que preconizou o Estado Democrático de Direito e estabeleceu como um de seus fundamentos a dignidade da pessoa humana.

Atentar-se-á que a legislação pátria contemporânea fora elaborada com vistas a promover a igualdade entre todos, com ênfase nos interesses coletivos, e, para alcançar esse fim, os direitos individuais sofreram uma relativização, dentre eles o direito de propriedade.

Diante do controle das ilicitudes e dos abusos de direito, estabelecido pelas normativas, cabe ao Poder Judiciário aplicar os dispositivos legais, validando o princípio da função socioambiental da propriedade.

Nesse sentido, será apreciada na pesquisaa decisão proferida pelo Tribunal de Justiça do Estado de São Paulo, datada de 19 de setembro de 2013, decorrente da Ação Civil Pública ajuizada pelo Ministério Público estadual, que objetivou a recuperação de área de preservação 
permanente e a constituição de reserva legal, com fundamento na Constituição da República

Federativa do Brasil de 1988, bem como o Código Civil/2002 e o Código Floresta1/2012.

Por fim, o objetivo desse trabalho é apresentar um estudo e uma reflexão sobre a importância da concreta efetivação da função socioambiental da propriedade, para que o direito fundamental ao meio ambiente ecologicamente equilibrado possa ser alcançado, viabilizando uma sadia qualidade de vida de todos, Bem como, apurar a responsabilidade civil do proprietário que olvida de suas obrigações para com esse dever.

\section{CONTORNOS HISTÓRICOS DA PROPRIEDADE}

O instituto da propriedade está inserido na civilização desde os tempos mais antigos, podendo o seu estudo ser considerado uma obra prima da Ciência da História. Tal afirmativa se justifica pelas preciosidades encontradas, como o Código de Hamurabi, que remonta a 1.700 a.C, considerado a compilação jurídica mais remota já descoberta. Seu texto estabelecia regras de vida e propriedade, ao longo dos seus 281 preceitos.

Merecem destaque alguns dispositivos que tratam da propriedade:

[...] 6. Se alguém roubar a propriedade de um templo ou corte, ele deve ser condenado à morte, e também aquele que receber o produto do roubo do ladrão deve ser igualmente condenado à morte.

7. Se alguém comprar o filho ou o escravo de outro homemsemtestemunhas ou um contrato, prata ou ouro, umescravo ou escrava, umboi ou ovelha, uma cabra ou seja o que for, se ele tomar este bem, este alguémserá considerado umladrão e deverá ser condenado à morte.

8. Se alguém roubar gado ou ovelhas, ou uma cabra, ou asno, ou porco, se este animal pertencer a um deus ou à corte, o ladrão deverá pagar trinta vezes o valor do furto; se tais bens pertencerema um homem libertado que serve ao rei, es te alguém deverá pagar 10 vezes o valor do furto, e se o ladrão não tiver com o que pagar seu furto, então ele deverá ser condenado à morte.

9. Se alguémperder algo e encontrar este objeto na posse de outro: se a pessoa em cuja posse estiver o objeto dis ser " um mercador vendeu isto para mim, eu paguei por este objeto na frente de testemunhas" e se o proprietário disse" eu trarei testemunhas para que conhecem minha propriedade" , então o comprador deverá trazer o mercador de quem comprou o objeto e as testemunhas que o viram fazer isto, e o proprietário deverá trazer testemunhas que possam identificar sua propriedade. O juiz deve examinar os testemunhos dos dois lados, inclusive o das testemunhas. Se o mercador for considerado pelas provas ser um ladrão, ele deverá ser condenado à morte. $\mathrm{O}$ dono do artigo perdido recebe então sua propriedade $\mathrm{e}$ aquele que a comprou recebe o dinheiro pago por ela das posses do mercador. (CÓDIGO DE HAMURABI). 
Percebe-se a preocupação com o roubo das propriedades e o rigor nas sanções, no caso de descumprimento dos preceitos. Extrai-se, também a previsão da posse; naquela época o instituto dos direitos reais ganhava seus primeiros contornos.

Já no Direito Romano a propriedade era configurada como um direito individual, absoluto e sacro. A sua caracterização tem raiz na composição da família, mediante o exercício do poder pelo pai - paterfamilias, considerado o chefe da casa e titular da soberania familiar, sem limitação pelo exterior.

Nas palavras de Giovanni Pellerino:

Em Roma, o regime de bens conhecia divers as formas de pertencimento. Àquela que só impropriamente podemos chamar de propriedade de gens, juntava-se o heredium, uma pequena quantidade de terra, geralmente contígua à habitação, necessária para fazer as necessidades primárias do restrito núcleo familiar. Além disso, encontravam-se várias formas de condomínio e comunhão, como o consortium interfratres. No que concerne à propriedade individual, distinta daquela do pater familias, sua afirmação foi gradual, em princípio referindo-se apenas aos bens móveis. Também no que concerne às fontes jurídicas não existia um único modelo de dominium: a propriedade quiritária se distinguia in bonishabere e ambas se contrapunham à unundominium que se aplicava aos peregrini nas periferias do Império. (PELLERINO, 2005, p. 38).

No período feudal a propriedade sofre uma mudança na sua feição, podendo ser percebida, mesmo que timidamente, a prática de uma função social. Isto porque o senhor feudal, detentor da propriedade e do poder, concedia as terras aos vassalos, que passavam a dever-lhe obrigações. Assevera Guilherme José Purvin de Figueiredo: "a relação do agricultor com o seu senhor era de dominação e subordinação, cabendo ao vassalo cultivar as terras e ao senhor oferecer-lhe proteção." (FIGUEIREDO, 2010, p. 60)

Sendo assim, a propriedade tinha uma configuração produtiva, pois os agricultores, através da lavoura, colhiam os frutos oriundos da terra, atendendo às necessidades da família que se encontrava a ela ligada, desvencilhando-se da característica de um direito absoluto, como ocorria no Direito Romano.

Todavia, a função social, identificada na idade média com os senhores feudais e seus vassalos, perde força com o fim do feudalismo. Isso se deve a Idade Moderna, com especial atenção para seus os movimentos culturais - Renascimento e Iluminismo, ocorridos entre os séculos XV e XVIII. Nesse período, vários foram os pensadores que colaboraram para o desenvolvimento do direito natural enquanto fundamental e individual, incluindo nesse rol a proteção ao bem do particular, mediante a lei civil.

Filósofos como Thomas Hobbes, John Locke, Jean Jacques Rousseau e Charles de 
Montesquieu entendiam que o direito à propriedade privada deveria ser positivado, por meio de lei oriunda do Estado, já que reconheciam sua necessidade para a organização da sociedade, o que era visto como Contrato Social, decorrente do contratualismo entre indivíduos e o poder público.

Tal construção de pensamento encontrava consonância com o período mercantilista vivenciado na época, e culminou na positivação do direito de propriedade em três diplomas importantes: Carta Constitucional Norte-americana, Convenção da Filadelphia e Declaração dos Direitos do Homem e do Cidadão, que assim dispôs, na França em 26 de agosto de 1789, sobre o direito de propriedade:

Art. $2^{\circ}$. A finalidade de toda as sociação política é a conservação dos direitos naturais e imprescritíveis do homem Esses direitos são a liberdade, a propriedade a segurança e a resistência à opressão.

Art. $4^{\circ}$. A liberdade consiste em poder fazer tudo que não prejudique o próximo. Assim, o exercício dos direitos naturais de cada homem não tem por limites senão aqueles que asseguram aos outros membros da sociedade o gozo dos mesmos direitos. Estes limites apenas podemser determinados pela lei.

Art. 17. ${ }^{\circ}$ Como a propriedade é um direito inviolável e sagrado, ninguémdela pode ser privado, a não ser quando a necessidade pública legalmente comprovada o exigir e sob condição de justa e prévia indenização. (DECLARAÇÃO DOS DIREITOS DO HOMEM E DO CIDADÃO, 1789).

No Século XIX, em 1804, surgiu o Código Civil Francês, conhecido como "Código Napoleônico", considerado o marco do individualismo jurídico, especificamente no que tange à propriedade. A normativa em questão consolidou o Estado Liberal, com o viés capitalista e patrimonialista, almejado pela classe burguesa na Revolução Francesa.

A legislação francesa inspirou diversos diplomas no mundo ocidental, tanto no século XIX, quanto na primeira metade do século XX, incluindo o Brasil, com a edição do Código Civil de 1916, vigente até 2002.

Mediante a positivação, o Estado garante o direito à propriedade privada, conferindo força ao proprietário, uma vez que pode utilizar, usufruir e dispor do seu bem de acordo com a sua conveniência, sem interferências e impedimentos, desconsiderando qualquer obrigação para com a coletividade, salvo mínimas delimitações de ordem pública.

O reconhecimento e a tutela do direito à propriedade privada era considerado como uma das formas de se alcançar a felicidade. Nas palavras de Aristóteles: "Parece, não sem razão, que os homens ajuízam do bem e da felicidade pelo seu gênero de vida. A maioria e os 
mais rudes acham que seja o prazer, e por isso outra vida não amam senão a dos gozos." (ARISTÓTELES, 1995, p. 29)

A mudança significativa da feição da propriedade com o viés de função social surge no Século XX, destacando-se as Constituições do México, em 1917 e a Constituição de Weimar, em 1919, consideradas marcos na elevação da teoria da função social como princípio que deva ser tutelado pelo Estado, através de sua lei fundamental.

Com a crise do Estado Liberal, agravada pelas duas guerras mundiais do Século XX, em 10 de dezembro de 1948 a Organização das Nações Unidas - ONU adotou a Declaração Universal dos Direitos Humanos, que se tornou um marco para a civilização. Neste documento merece destaque: "Artigo XVII: 1 - Todo o ser humano tem direito à propriedade, só ou em sociedade com os outros; 2 - Ninguém pode ser arbitrariamente privado da sua propriedade" (1948).

A respeito de tal mudança discorre Jurgen Habermas: “ Após o término da II Guerra, a mudança da ordem do direito privado, introduzida durante o regime do Nacional-socialis mo, desencadeara reações morais contra o "destronamento" e o solapamento moral do direito subjetivo" (HABERMAS, 2012, p. 119)

No Brasil a Carta Constitucional do Governo de Getúlio Vargas de 1934 foi a primeira que regulamentou a propriedade considerando o interesse coletivo, conforme preceitua seu artigo 113:

Art 113 - A Constituição assegura a brasileiros e a estrangeiros residentes no País a inviolabilidade dos direitos concernentes à liberdade, à subsistência, à segurança individual e à propriedade, nos termos seguintes:

[...]

17) É garantido o direito de propriedade, que não poderá ser exercido contra o interesse social ou coletivo, na forma que a lei determinar. A desapropriação por necessidade ou utilidade pública far-se-á nos termos da lei, mediante prévia e justa indenização. Em caso de perigo iminente, como guerra ou comoção intestina, poderão as autoridades competentes usar da propriedade particular até onde o bem público o exija, res salvado o direito à indenização ulterior. (BRASIL, 1934).

Após esse diploma constitucional, outros dispositivos legais surgiram no país ainda no Século XX, mas a configuração do instituto da propriedade enquanto função socioambiental somente foi consolidada com a promulgação da atual Constituição da República de 1988, que culminou em várias normativas, como o Código Civil de 2002 e o atual Código Florestal de 2012, conforme a seguir será elucidado. 


\section{A FUNÇÃO SOCIOAMBIENTAL DA PROPRIEDADE NO BRASIL}

O breve contexto histórico demonstrou que o instituto da propriedade passou por várias mudanças desde os primórdios e, no Brasil não foi diferente. Mesmo possuindo menos de 200 anos de histórico constitucional, uma vez que o primeiro diploma constitucional fora estabelecido na primeira metade do século XIX-Constituição Política do Império do Brazil, 25 de março de 1824, o ordenamento jurídico pátrio também sofreu mudanças no que se refere às configurações e caracterizações do conceito de propriedade.

Todavia, no que tange a função social da propriedade somente com a Constituição anterior, promulgada em 1967, sua previsão fora incluída: "Art. 157 - A ordem econômica tem por fim realizar a justiça social, com base nos seguintes princípios: [...] III - função social da propriedade" (BRASIL, 1967)

No campo das legislações infraconstitucionais, antes da promulgação da Constituição da República de 1988, algumas normativas regulamentaram o direito de propriedade com a função socioambiental, destacando-se o primeiro Código Florestal Brasileiro, Decreto $\mathrm{n}^{\circ}$ 23.793/1934, revogado pela Lei $\mathrm{n}^{\mathrm{o}}$ 4.771/1965. A importância de tal dispositivo legal é identificada nas palavras de Norma Sueli Padilha: “... mencionou pela primeira vez a obrigatoriedade de proteção de um percentual de vegetação espontânea no interior das propriedades rurais no limite de $25 \%$. O Código previu também alguns tipos penais de crimes florestais". (PADILHA, 2010, p. 103)

Em 1937 foi promulgado o Decreto-lei $\mathrm{n}^{\circ} 25$, de 30 de novembro de 1937, que organizou a proteção do patrimônio histórico e artístico nacional, que pode restringir o uso da propriedade do particular caso a mesma seja tombada, segundo se extrai: "Art. 12 - A alienabilidade das obras históricas ou artísticas, de propriedade de pessoas naturais ou jurídicas de direito privado sofrerá as restrições constantes da presente lei” (Brasil, 1937).

A referida legislação, que estabeleceu as regras de tombamento, há quase 80 anos,ainda está vigente, pois foi recepcionada pela Constituição da República de 1988, e encontra consonância com o artigo 216 do referido diploma constitucional:

Art. 216 - Constituempatrimônio cultural brasileiro os bens de natureza material e imaterial, tomados individualmente ou em conjunto, portadores de referência à identidade, à ação, à memória dos diferentes grupos formadores da sociedade brasileira, nos quais se incluem 
[...]

$\S 1^{\circ}$ O Poder Público, com a colaboração da comunidade, promoverá e protegerá o patrimônio cultural brasileiro, por meio de inventários, registros, vigilância, tombamento e des apropriação, e de outras formas de acautelamento e preservação.

[...]

$\S 4^{\circ}$ Ficam tombados todos os documentos e sítios detentores de reminiscências his tóricas dos antigos quilombos. (BRASIL, 1988)

Na segunda metade do século XX, foi promulgada a Lei $\mathrm{n}^{\circ} 4.771 / 1965$, revogando o primeiro Código Florestal, criado 30 anos antes. A legislação foi muito importante para a tutela ambiental, visto que limitou o exercício do direito de propriedade mediante a instauração obrigatória da Área de Preservação Permanente e a Reserva Legal, considerando que se trata de interesse comum a todos os brasileiros. Todavia, a referida legislação fora revogada pelo atual Código Florestal, Lei no 12.651, de 25 de maio de 2012.

Merecem apontamentos também a Lei $\mathrm{n}^{\circ}$ 6.513/1977, que dispõe sobre a criação de áreas especiais e de locais de interesse turístico, de bens de valor cultural e natural, que estabeleceu restrições ao uso da propriedade privada, em prol do interesse coletivo; a Lei $\mathrm{n}^{\circ}$ 6.766/1979, que estipulou as regras para o parcelamento do solo urbano, posteriormente revogada pela Lei $n^{\circ} 9.785 / 1999$; e a Lei $n^{\circ} 6.803 / 1980$, que regulamentou as diretrizes básicas para o zoneamento industrial.

Não restam dúvidas que dentre todas as legislações infraconstitucionais que estabeleceram normativas para a tutela do meio ambiente a mais abrangente é a Lei $\mathrm{n}^{\circ}$ 6.938/1981, visto que criou a Política Nacional do Meio Ambiente, com preceitos que restringem o direito da propriedade privada, como: "Art. 10 - A construção, instalação, ampliação e funcionamento do estabelecimento e atividades utilizadores de recursos ambientais, efetiva ou potencialmente poluidores ou capazes, sob qualquer forma, de causar degradação ambiental do prévio licenciamento ambiental.” (BRASIL, 1981)

Sobre a relevância da referida lei para o direito pátrio elucida Norma Sueli Padilha:

A Lei de Política Nacional do Meio Ambiente pode ser considerada como a mais importante legis lação infraconstitucional anterior à Constituição Federal de 1988, pois introduziu, no ordenamento jurídico brasileiro, um novo tratamento normativo para o meio ambiente, numa visão holística que muito se aproximou do gigantesco passo do texto constitucional de 1988, razão pela qual foi inteiramente albergada e recepcionada pela nova Carta.

....estabelece os objetivos e instrumentos da Política Nacional do Meio Ambiente, além de estabelecer um sistema de responsabilidades por danos ao meio ambiente, que abrange a área administrativa e a responsabilidade objetiva na seara civil, independente da respons abilidade penal (art. 14, $\S 1^{\circ}$ ). (PADILHA, 2010, p. 110111) 
Um dos dispositivos mais inovadores da Lei $n^{\circ}$ 6.938/81 é a responsabilidade civil objetiva, que pode implicar na punição do proprietário que não utilizar o seu bem em conformidade com o princípio socioambiental, independente de sua culpabilidade, visto que o objetivo é a proteção do meio ambiente. Para Nelson Rosenvald “... no âmbito da tutela ambiental e dos direitos da personalidade o recurso à responsabilidade civil como instrumento de controle deverá receber adequada consideração" (ROSENVALD, 2013, p. 75).

No entendimento de Guilherme José Purvin de Figueiredo a Lei ${ }^{\circ}$ 6.938/1981 possui um papel relevante para a regulamentação do Direito Ambiental, inclusive no que tange ao direito de propriedade:

A Lei $\mathrm{n}^{\circ}$ 6.938/1981, ademais, trouxe ao nosso ordenamento jurídico conceitos basilares do Direito Ambiental, como o do poluidor e poluição, além da regra da res pons abilidade civil objetiva por dano ambiental. Todos os elementos constantes nesse diploma fundamental do Direito Ambiental brasileiro são úteis para a implementação do princípio da função social da propriedade em conjunto comas já mencionadas disposições do Código Civil de 2002. (FIGUEIREDO, 2010, p. 135)

Após o marco histórico na legislação do Direito Ambiental, representada pela Lei $\mathrm{n}^{\mathrm{o}}$ 6.938/1981, o ordenamento jurídico brasileiro foi contemplado com a Carta Constitucional de 1988, que recepcionou a referida lei, e dedicou um capítulo para a tutela do Meio Ambiente, Capítulo VI, além de estabelecer em outros dispositivos sobre o tema. Sobre a propriedade privada, o legislador constituinte estabeleceu a sua "função social" em 07 artigos, como será analisado a seguir.

\subsection{As limitações ao direito de propriedade estabelecidas pela Constituição da República} Federativa de 1988

A Carta Constitucional vigente no Brasil elenca diversos direitos sociais, sendo que muitos possuem caráter difuso. Em decorrência dessa característica tornou-se conhecida como "Constituição Cidadã e Ambientalista", visto que inovou ao estabelecer um extenso rol de direitos fundamentais, além de dedicar tratamento a temas até então pouco explorados ou sequer previstos, como a tutela do meio ambiente. 
Especificamente às limitações ao direito de propriedade o legislador constituinte dedicou significativa atenção, segundo observa Paulo Affonso Leme Machado: "Pelo menos oito vezes a expressão "função social" está presente na Constituição: arts. 5', XXIII; 170, III; 173, § 1º I; 182, caput; 182, § 2º 184, caput; 185, parágrafo único; e 186, III.” (MACHADO, 2015, p. 175)

E sobre a função social da propriedade explana o mesmo Autor:

Reconhecer que a propriedade tem também, uma função social é não tratar a propriedade como um ente isolado na sociedade. Afirmar que a propriedade tem uma função social não é transformá-la em vítima da sociedade. A fruição da propriedade não pode legitimar a emissão de poluentes que vão invadir a propriedade de outros indivíduos. $O$ conteúdo da propriedade não reside num só elemento. Há o elemento individual, que possibilita o gozo e o lucro para o proprietário. Mas outros elementos aglutinam-se a esse: além do fator social, há o componente ambiental. (MACHADO, 1994, p. 127)

Após a análise dos dispositivos constitucionais acima listados, dúvidas não restam que a Constituição atual condicionou ao direito de propriedade a função socioambiental, que se encontra diretamente vinculada ao dever de desenvolvimento sustentável. É o que se observa com os seguintes dispositivos constitucionais:

Art. 182. A política de desenvolvimento urbano, executada pelo Poder Público municipal, conforme diretrizes gerais fixadas em lei tem por objetivo ordenar o pleno desenvolvimento das funções sociais da cidade e garantir o bem- estar de seus habitantes.

[...]

$\S 2^{\circ}$ A propriedade urbana cumpre sua função social quando atende às exigências fundamentais de ordenação da cidade expressas no plano diretor.

Art. 184. Compete à União desapropriar por interesse social, para fins de reforma agrária, o imóvel rural que não esteja cumprindo sua função social, mediante prévia e justa indenização em títulos da dívida agrária, com cláusula de preservação do valor real, resgatáveis no prazo de até vinte anos, a partir do segundo ano de sua emis são, e cuja utilização será definida emlei.

Art. 185. São insuscetíveis de desapropriação para fins de reforma agrária:

[...]

Parágrafo único. A lei garantirá tratamento especialà propriedade produtiva e fixará normas para o cumprimento dos requisitos relativos a sua função social.

Art. 186. A função social é cumprida quando a propriedade rural atende, simultaneamente, segundo critérios e graus de exigência estabelecidos em lei, aos seguintes requisitos:

II - utilização adequada dos recursos naturais disponíveis e preservação do mei o ambiente; (BRASIL, 1988)

Percebe-se que tanto a propriedade urbana, quanto a rural possuem a obrigação de cumprir a função socioambiental, o que implica, necessariamente, em limitações ao direito do proprietário e, caso ocorra descumprimento de tal dever sanções poderão ser aplicadas, como a desapropriação. 
Sobre as sanções, quando da inobservância dos preceitos que envolvem o direito de propriedade, manifestou o Ministro Celso de Mello, do Supremo Tribunal Federal, ao julgar ação de Mandado de Segurança sobre reforma agrária: "A defesa da integridade do meio ambiente, quando venha a constituir objeto de atividade predatória, pode justificar atividade estatal veiculadora de medidas - como a desapropriação-sanção - que atinjam o próprio direito de propriedade" (BRASIL, STF, 1995)

Nas palavras de Elcio Nacur Rezende e Daniela Oliveira Gonçalves: "Considerando que a função socioambiental da propriedade somente estará cumprida se todos os requisitos estiverem simultaneamente obedecidos, até mesmo terras produtivas estarão sujeitas à desapropriação para fins de reforma agrária” (REZENDE e GONÇALVES, 2013, p. 133).

A respeito das restrições da propriedade consideram Ingo Wolfgang Sarlet e Tiago Fensterseifer:

\begin{abstract}
De acordo com a leitura dos dispositivos referidos, resulta evidente a importância dos institutos jurídicos emquestão para a manutenção e equilíbrio dos ecossistemas onde as propriedades rurais e urbanas encontram-se situadas. Tal enquadramento normativo, é importante reiterar, conduza uma tutela ecológica compartilhada entre o Es tado e os atores privados (pessoas físicas e jurídicas), de modo que ambos (setor público e privado) as sumam parcela da res ponsabilidade, e, portanto, cumpram com as obrigações para com a manutenção da qualidade, da segurança e do equilíbrio ambiental. (SARLET e FENSTERSEIFER, 2012, p. 177)
\end{abstract}

No tocante a "tutela ecológica compartilhada entre Estado e os atores privados", mencionada pelos autores acima, observa-se que existe uma responsabilidade social para com os interesses coletivos, especificamente com a proteção do meio ambiente, visto que se trata de um direito difuso. Tal tutela deve ser praticada por todos, conforme preceitua o artigo 225 da Carta Constitucional de 1988: "Todos têm direito ao meio ambiente ecologicamente equilibrado, bem de uso comum do povo e essencial à sadia qualidade de vida, impondo-se ao Poder Público e à coletividade o dever de defendê-lo e preservá-lo para as presentes e futuras gerações”. (BRASIL, 1988)

Com base no exame e estudo de todos os dispositivos constitucionais citados, especialmente o artigo 225, resta claramente demonstrado que fora abandonado pelo legislador constituinte a feição individualista do direito privado, que prevaleceu no Código Civil de Clóvis Beviláqua de 1916 até o de Miguel Reale de 2002, passando a propriedade a ser configurada com a função socioambiental, já que o interesse coletivo passou a ser tutelado 
de forma abrangente, atingindo os direitos individuais. Acerca de tal questão, que envolve o direito à propriedade e o direito social, discorre Nelson Rosenvald:

\begin{abstract}
Se por um ângulo o princípio de proteção ao direito de propriedade e da liberdade econômica reclamam uma regra que limite a reparação à medida dos prejuízos sofridos pela vítima, de outro vértice, reclamam balanceamento os princípios que protegem direitos metaindividuais, alicerçados nos valores da integridade e da dignidade da pes soa humana (ROSENVALD, 2013, p. 93)
\end{abstract}

Mediante a atual formatação exige-se do proprietário uma postura negativa, mas também ativa e positiva, não se limitando à exploração econômica do bem, mas também ao exercício de modo racional e sustentável, o que implica em cumprimento de deveres sociais, com vistas a atender aos interesses da coletividade.

Em função do caráter socioambiental estabelecido à propriedade, encontra-se o proprietário sujeito às restrições e imposições determinadas pelo Estado, que recebeu na Constituição da República de 1988 a atribuição de proporcionar o bem-estar a todos, mesmo que tenha que limitar direitos individuais até outrora considerados absolutos e intocáveis. Nas palavras de Michael Sandel: “... a justiça requer diretrizes que corrijam as desvantagens sociais e econômicas e que dêem a todos oportunidades justas de sucesso". (SANDEL, 2011, p. 29)

Sobre a necessidade da intervenção do Estado, com vistas à proteção da coletividade, explana Nelson Rosenvald:

Para a proteção dos valores da pessoa - com relação aos quais o mercado é frequentemente indiferente - propõe-se o recurso ao mecanis mo da solidariedade para que prevaleçamos direitos da pessoa sobre as decisões econômicas. A mão pública regula o jogo corret o das forças do mercado, as sumindo o papel de defender o indivíduo de suas agressões. (ROSENVALD, 2013, p. 78)

Percebe-se que o papel do Estado Social é importante para salvaguardar os direitos que envolvem toda a sociedade, considerados difusos. Desta maneira, face às novas diretrizes estabelecidas pela atual Carta Constitucional deve o regime jurídico da propriedade abarcar a proteção ambiental. E diante do contemporâneo tratamento dispensado, as legislações infraconstitucionais vêm sendo elaboradas para atender os ditames preconizados pelo legislador constituinte.

No tocante a adequação do direito positivo à temática ambiental, que inclui as tratativas referentes à propriedade, assevera Hans Jonas: 
Questões que nunca foram antes objeto de legis lação ingressamno circuito das leis que a "cidade" global tem de formular, para que possa existir um mundo para as próximas gerações.

Aceita-se facilmente, como axioma universal ou como um convincente desejo da fantasia especulativa, a ideia de que tal mundo adequado à habitação humana deva continuar a existir no futuro, habitado por uma humanidade digna desse nome (ideia tão convincente e tão incomprovável como a assertiva de que a existência de um mundo é sempre melhor do que a existência de nenhum), mas, como proposição moral, is to é, como uma obrigação prática perante a posteridade de um futuro distante, e como princípio de decisão na ação presente, a as sertiva é muito distinta dos imperativos da antiga ética da simultaneidade, e ela somente ingressou na cena moral comos noss os poderes e o novo alcance da nossa capacidade de previsão.

Dentre as várias normativas promulgadas após a Constituição de 1988 merecem destaque dois diplomas que disciplinam o instituto da propriedade privada, quais sejam o Código Civil de 2002 e o Código Florestal de 2012. Ambos são importantes para a compreensão do novo viés prescrito para o direito de propriedade, à luz do direito fundamental ao meio ambiente ecologicamente equilibrado. A seguir, demonstrar-se-á a aplicação de tais dispositivos pelo Poder Judiciário, especificamente no julgamento da Ação Civil Pública ajuizada pelo Ministério Público estadual de São Paulo, que objetivou a recuperação de área de preservação permanente e a constituição de reserva legal.

\section{A APLICAÇÃO DA FUNÇÃO SOCIOAMBIENTAL DA PROPRIEDADE EM SEDE DE DECISÃO JUDICIAL}

Em consonância com o Estado Social, adotado pela República Federativa Brasileira com a promulgação da Constituição de 1988, o Código Civil de 2002 estabeleceu como um de seus princípios a função social, conforme se depreende da leitura do parágrafo único do art. 2035: "Nenhuma convenção prevalecerá se contrariar preceitos de ordem pública, tais como estabelecidos por este Código para a assegurar a função social da propriedade e dos contratos". (BRASIL, 2002)

No Título III, Capítulo I, do diploma civil em comento, o legislador estabeleceu todas as normativas referentes ao instituto da propriedade e, adotou, já no primeiro artigo sobre a matéria, o princípio socioambiental, segundo se extrai do dispositivo:

Art. 1228 - O proprietário temdireito de usar, gozar e dispor da coisa, e o direito de reavê-la do poder de quemquer que injustamente a possua ou detenha.

Parágrafo único - $\mathrm{O}$ direito de propriedade deve ser exercido em cons onância comas suas finalidades econômicas e sociais e de modo que sejam preservados, de conformidade com lei especial, a flora, a fauna, as belezas naturais, o equilíbrio 
ecológico e o patrimônio his tórico e artístico, bem como evitada a poluição do ar e das águas. (BRASIL, 2002)

Percebe-se a harmonia entre o atual Código Civil e a Carta Constitucional vigente no que tange ao tratamento das funções da propriedade. Nesse sentido Bruno Miragem: “... a função social da propriedade relacionada no catálogo de direitos fundamentais tem como primeira consequiência a vinculação, desde o ápice da pirâmide normativa, da correlação entre o direito subjetivo de propriedade e o dever jurídico oponível ao seu exercício, de cumprimento a respectiva finalidade social" (MIRAGEM, 2005, p. 105)

O proprietário adquiriu o dever de observar os interesses do outro, não considerando apenas a sua individualidade e satisfação, já que se objetiva o bem-estar da comunidade.

Com a nova feição, a propriedade passou a ser influenciada diretamente pelo princípio da função social, com adaptação aos direitos coletivos e difusos, adotados na sociedade democrática contemporânea, visando alcançar o bem comum de todos.

Nessa linha de tutela do meio ambiente, que implica na restrição dos direitos do proprietário, com imposição de um poder-dever à propriedade, em atendimento à sua função socioambiental, em 2012 fora promulgado o novo Código Florestal, representado pela Lei $\mathrm{n}^{\circ}$ $12.651 / 2012$

Como já fora elucidado, a Constituição da República estabeleceu limites e determinou requisitos que devem ser cumpridos pelos proprietários rurais, sob pena de aplicações de sanções, como a desapropriação.

A respeito da propriedade rural e sua função social discorrem Maristela Aparecida de Oliveira Valadão e Paula Santos de Araújo:

A propriedade rural representa muito mais do que umbem patrimonial, é um bem de produção que deve atingir um fim sociale ambiental para cumprir sua função social. É cristalina a exigência de que a propriedade deva ser produtiva, e os lucros, oriundos de sua exploração econômica, só serão legítimos se houver a preservação dos recursos naturais. (VALADÃOe ARAÚJO, 2013, p. 142)

Para Paulo Affonso Machado:

Na Lei 12.651/2012 merecem ser apontados dois de seus fundamentos: a "proteçãoe uso sustentável das florestas e demais formas de vegetação nativa em harmonia com a promoção do desenvolvimento econômico" (art. $1^{\circ}$ - A) e a afirmação de que "as flores tas são bens de interesse comuma todos dos habitantes do País" (art. $2^{\circ}$, caput) (MACHADO, 2015, p. 873)

Já sobre as funções da propriedade, considerando as normativas Constitucionais, do Código Civil e do atual Código Florestal, ensina o mesmo Autor: 
A propriedade rural deve atender à sua função social e à sua função individual, integrando-se as duas funções. A propriedadenão é um direito individual que exis ta para se opor à sociedade. É um direito que se afirma na comunhão coma sociedade. (...) A função social da propriedade faz com que o proprietário não possa usar da propriedade de acordo somente com sua vontade pessoal, mas tem que informar aos outros integrantes da sociedade o que faz e porque faz. (...)

$\mathrm{O}$ aproveitamento racional e adequado da propriedade rural mostra que o bem imóvel não é um museu e nem uma reserva biológica em toda a sua extensão. A tecnologia deve guiar a gestão da propriedade de forma racional, visando ao seu êxito econômico, sem que com isso se deixe de preservar o meio ambiente. (MACHADO, 2015, p. 875)

Dentre os deveres sociais impostos à propriedade encontram-se o de torná-la produtiva e de não degradar o meio ambiente e, para que esse último seja efetivado, a legislação trouxe limitações ao seu exercício, como a exigência de espaços territoriais denominados Área de Preservação Permanente - APP e Reserva Legal, conforme estabelece o Código Florestal. E, nas palavras de Guilherme José Purvin de Figueiredo: "Estes dois condicionamentos legais ao direito de propriedade imobiliária constituem obrigações propterrem [...]" (FIGUEIREDO, 2010, p. 234)

Diante das regras do ordenamento jurídico brasileiro que estabelecem requisitos para o exercício do direito de propriedade, especialmente estipulou a função socioambiental, quando ocorre seu descumprimento cabe ao Poder Judiciário aplicar as sanções previstas, com vistas à efetivar a tutela do meio ambiente.

Nesse sentido, merece atenção a decisão proferida pelo Tribunal de Justiça do Estado de São Paulo no julgamento da Ação Civil Pública ajuizada pelo Ministério Público estadual em desfavor de duas pessoas naturais, em função da inobservância das determinações legais no que tange a Área de Preservação Permanente e Reserva Legal:

AÇÃO CIVIL PÚBLICA. Recuperação de área de preservação permanente e constituição de reserva legal. Procedência dos pedidos. Pres crição não caracterizada. Danos ambientais que se renovamconstantemente e se prolongamenquanto não for cessada a conduta irregular e reparada a degradação. Aplicação da Lei n. $12.651 / 2012$ no caso concreto. Intervenção irregular na área de preservação permanente e ausência de constituição da reserva legal evidenciadas. Obrigação ambiental de natureza objetiva(art. $14, \S 1^{\circ}$, da Lei n. 6.938/1981) e propter rem (art. $2^{\circ}, \S 2^{\circ}$, da Lei n. 12.651/2012). Dever de constituição e de recuperação desses espaços territoriais, nos termos da Constituição Federal e do Código Florestal vigente. Polo passivo que pode ser formado pelo poluidor direto ouindireto. Aplicação do princípio da função socioambiental da propriedade. Normas de Direito Ambiental consideradas de ordempública e de aplicação cogente e imediata. Imóvel com dimensão inferior a 1 módulo fiscal. Requisitos para a aplicação dos arts. 61-A, 
66 e 67 do Código Florestal que deverão ser verificados pelo MM. Juízo a quo, na fase de execução, a fim de evitar cerceamento do direito de defes a da outra parte e supressão de instância. Necessidade de averbação da reserva legal enquanto não implantado o Cadas tro Ambiental Rural. Sentença reformada em parte.RECURSO PARCIALMENTE PROVIDO. (BRASIL, São Paulo, 19/09/2013)

Ao analisar todo o acórdão, um fato chama a atenção: a câmara julgadora é reservada ao Meio Ambiente. Tal organização do Poder Judiciário estadual de São Paulo é, sem dúvida, um dos motivos que resultou na adoção dos dispositivos legais que tratam da função socioambiental da propriedade. A Ementa, acima descrita, já elucida com clareza que foram aplicadas as normativas preconizadas pela Constituição da República Federativa do Brasil de 1988, pela Lei da Política Nacional do Meio Ambiente e pelo atual Código Florestal.

Torna-se perceptível o apropriado emprego do ordenamento jurídico quando da leitura do voto proferido pelo Relator Paulo Alices Amaral Salles:

Sua criação objetiva garantir a proteção de cobertura vegetal mínima na propriedade rural, visando não apenas a manutenção da qualidade de ecossistemas e da biodiversidade locale regional, mas também a proteção ampla de biomas e de seus processos ecológicos associados. As áreas de preservação permanente, diferentemente, têm por fim a proteção de fragilidades ambientais.É indiscutível a obrigatoriedade de manutenção desses instrumentos de tutela, que deriva do mandamento constitucional que exige postura ativa do Poder Público e da sociedade para a proteção do meio ambiente ecologicamente equilibrado (art. 225, caput, da Constituição Federal).

Saliente-se, ainda, que a Lei n.12.651/2012 não admite o uso das propriedades semo respeito das regras atinentes à reserva legal e às áreas de preservação permanente, pois todos os imóveis rurais, independentemente da destinação outrora dada às terras, estão sujeitos à obrigação de instituí-la e mantê-la. 
A reserva legal, as simcomo as áreas de pres ervação permanente, representamônus inerente ao direito de propriedade, a teor do art. 186, inc. II, da Constituição Federal, ao es tabelecer que a função social do imóvelé cumprida apenas quando se constatar a utilização adequada dos recursos naturais disponíveis e a preservação do meio ambiente. Por tal razão, não são indenizáveis, pois integramo conteúdo do princípi o da função socioambiental da propriedade.Ademais, cumpre ressaltar que as normas de direito ambiental são de ordem pública e de aplicação cogente e imediata, descabendo falar em "ato jurídico perfeito"ou em "direito adquirido de poluir". Logo, a exploração da área, na forma pretendida pelos réus, implica uso nocivo da propriedade e não pode ser tolerada.(BRASIL, São Paulo, 19/09/2013)

Extrai-se do voto que o Magistrado entende que a propriedade não pode ser explorada de forma prejudicial, devendo o proprietário cumprir o que estabelecem as normas específicas do Direito Ambiental, que devem ser obedecidas, visto que são consideradas de ordem pública, não cabendo flexibilização, pois visam à proteção de interesses sociais.

Ressalta-se que uma câmara especializada na temática ambiental viabiliza que a legislação especial seja aplicada de forma adequada, em cumprimento ao objetivo maior que é o direito ao meio ambiente ecologicamente equilibrado, considerado, por grande parte da doutrina e da jurisprudência pátria, como direito fundamental.

Nesse sentido, o proprietário que descumprir seus deveres no que tange à função socioambiental da propriedade deverá sofrer as sanções decorrentes da imputação da responsabilidade objetiva por dano ambiental, prevista na Constituição da República, Código Civil e outras leis infraconstitucionais.

Cumpre destacar que a responsabilidade oriunda do dano ambiental é objetiva em função do respeito ao meio ambiente se basear em princípios sociais, com caráter difuso, e não individual. Sendo assim, como a culpa é pressuposto para a proteção do indivíduo, não pode ser inserida no contexto de proteção social do meio ambiente, direito e responsabilidade de todos, governo e sociedade.

Percebe-se a relevância da aplicação de tal instituto no tratamento do direito de propriedade, já que a responsabilidade ambiental decorre da necessidade de cumprimento da obrigação de respeito ao meio ambiente ecologicamente equilibrado. E a simples violação deste dever gera a responsabilidade de reparar o dano.

\section{CONSIDERAÇÕES FINAIS}


Após intensa pesquisa, o trabalho demonstrou que no Direito Contemporâneo, inaugurado pelo Estado Social, não mais existe o absolutismo da propriedade, presente nas legislações do Século XIX e até meados do Século XX.

A feição individual da propriedade positivada pelo Código Civil Brasileiro de 1916, inspirado no Código Napoleônico, não mais possui guarida, ao contrário, a atual configuração implica no dever do proprietário de cumprir a função socioambiental, prevista na Carta Constitucional vigente e em diversos outros diplomas legais por ela inspirados, dentre os quais o Código Civil de 2002.

Com a promulgação da Constituição da República Federativa de 1988, o direito fundamental à propriedade passou a ser vinculado direito ao dever de proteção ao meio ambiente ecologicamente equilibrado, encargo que cabe a todos, sem distinção.

O regime constitucional de propriedade estabelece que o proprietário deve ter uma postura ativa e positiva e negativa na utilização do seu bem e, caso assim não proceda, estará sujeito às sanções previstas. Isto porque é vedado o uso individual e egoístico, que implique na inatividade do bem, na sua ociosidade, decorrente do uso inadequado ou da ausência de aproveitamento da propriedade, que a torne infrutífera, cause a exclusão social e/ou relevantes impactos ambientais.

A irradiação da positividade das normativas constitucionais culminou na promulgação de um novo Código Civil, em 2002, que incorporou ao instituto da propriedade o dever de preservar o meio ambiente, quando determinou salvaguardar a biodiversidade, contemplada pela fauna e flora, conservar o patrimônio histórico e cultural, evitar a poluição do bioma, objetivando o equilibrio ecológico.

$\mathrm{Na}$ mesma linha de aplicação da função socioambiental da propriedade encontra-se o Código Florestal vigente desde 2012, que trouxe restrições, especialmente para os imóveis rurais, tanto no que tange ao uso racional e sustentável da terra, quanto na obrigação da criação de espaços territoriais protegidos para a preservação de recursos naturais, incluindo a fauna e a flora.

É importante destacar que o ordenamento jurídico analisado, Carta Constitucional e leis infraconstitucionais, não se suprimiu o direito individual à propriedade, mas sim impôs limites ao seu exercício, em conformidade com os interesses da comunidade. 
O dever de tutela ambiental proclamado implica que o proprietário de um bem visualize e reconheça também o direito do outro, resultando na concretização do princípio da solidariedade, no qual não ocorra a exclusão social, já que a miserabilidade e a pobreza são enormes fomentadoras dos impactos ambientais.

Dúvidas não restam que o Brasil possui um arcabouço jurídico que objetiva proteger o meio ambiente para que todos possam ter uma sadia qualidade de vida.

Primordial, então, é a aplicação efetivado princípio constitucional da função socioambiental da propriedade, e reforçar a ideia de que o homem precisa rever suas práticas individuais e egoístas. Tal princípio deve ser compreendido com o princípio da responsabilidade, uma vez que identificado o descumprimento do dever da função social, deve, o titular do bem, sofrer as sanções decorrentes da sua ação.

Assim, deve o proprietário, ciente de que possui deveres para com o meio ambiente quando da utilização do seu bem, se cercar de todos os cuidados possíveis, com vistas a cumprir integralmente as funções socioambientais da propriedade.

Para tanto o papel do Poder Judiciário é muito relevante, no sentido de aplicar adequadamente as normativas específicas da tutela ambiental, como a imputação da responsabilidade civil ambiental, especialmente no que tange à propriedade, mediante à submissão dos interesses patrimoniais aos direitos fundamentais.

É preciso alcançar um novo modo de olhar para a propriedade privada, devendo ser reconhecida a sua função social como princípio básico, a ela inerente. A mudança de comportamento de todos os agentes da sociedade contemporânea é fundamental para que o direito constitucional ao meio ambiente ecologicamente equilibrado e a sadia qualidade de vida sejam efetivamente concretizados e o uso adequado da propriedade, nos moldes estabelecidos pelo ordenamento jurídico, é uma das grandes ferramentas para o seu alcance.

\section{REFERÊNCIAS}


ARISTÓTELES. A Ética. Tradução de Paulo Cássio M. Fonseca. São Paulo: Edipro, 1995.

BRAGA NETTO, Felipe Peixoto; FARIAS, Cristiano Chaves e ROSENVALD, Nelson. Curso de Direito Civil. Responsabilidade Civil. Salvador: Jus Podivm, 2014.

BRASIL. Constituição da Re pública Fe de rativado B rasil. Congresso Nacional. Brasília, 1934. Disponível em:

http:/www.planalto.gov.br/ccivil_03/Constituicao/Constituicao34.htm

Brasîlia, 1967. Disponível

_-Cons tituição da Re pública Fe derativado B rasil. Congresso Nacional. em:http://www.planalto.gov.br/ccivil_03/Constituicao/Constituicao67.htm. Acesso em: 11 out.15.

_. Cons tituição da Re pública Federativado B rasil. Congresso Nacional. Brasîlia, 1988. Disponível em:

http:/www.planalto.gov.br/ccivil_03/constituicao/constituicaocompilado.htm Acesso em: 22 abr.15.

. Lei 6.938, de 31 de agosto de 1981. Dispõe sobre a política nacional do meio ambiente. Disponível em: http://www.planalto.gov.br/ccivil_03/leis/16938.htm. Acesso em: 22 abr. 15.

. Lei 10.406, de 10 de janeiro de 2002. Institui o Código Civil. Disponível

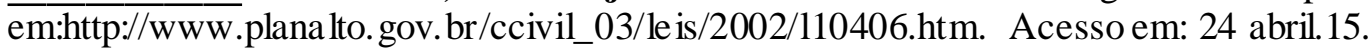

. Lei 12.651, de 10 de janeiro de 2012. Institui o Código Florestal. Disponível em: http://www.planalto.gov.br/ccivil_03/_ato2011-2014/2012/lei/112651.htm. Acesso em: 12 out. 15.

CÓDIGO DE HAMURABI. Disponível em:

http//www.direitoshumanos.usp.br/index.php/Documentos-anteriores-\%C3\% A0cria\%C3\% A7\%C3\% A3o-da-Sociedade-das-Na\%C3\% A7\%C3\%B5es-at\%C3\% A91919/codigo-de-hamurabi.html. Acesso em: 10 out.15

COSTA, Beatriz Souza. Meio Ambiente como direito à vida: B rasil, Portugal e Espanha. Rio de Janeiro: Lumen Juris, 2013.

DECLARAÇÃO DOS DIREITOS DO HOMEM E DO CIDADÃO. Disponível em: http://www.direitoshumanos.usp.br/index.php/Documentos-anteriores-\% C3\% A0cria\%C3\% A7\%C3\% A3o-da-Sociedade-das-Na\%C3\% A7\%C3\%B5es-at\%C3\% A91919/declaracao-de-direitos-do-homem-e-do-cidadao-1789.html. Acesso em: 10 out.15.

FERREIRA FILHO, Manuel Gonçalves. Comentários à Constituição B rasileira de 1988. $2^{\mathrm{a}}$ ed. São Paulo: Saraiva, 1999, v. 2, p. 276. 
FIGUEIREDO, Guilherme José Purvin. A propriedade no Direito Ambiental. $4^{\mathrm{a}}$ ed. rev., atual. eampl. São Paulo: Editora Revista dos Tribunais, 2010.

HABERMAS, Jurgen. Dire ito e Democracia: entre facticidade e validade. v. I. Tradução: Flávio Beno Siebeneichler. Rio de Janeiro: Tempo Brasileiro, 2012.

JONAS, HANS. O princípio responsabilidade: Ensaio de uma ética para a civilização tecnológica. Tradução de Luiz Barros Montez. Rio de Janeiro: Contraponto: Ed. PUC-Rio, 2006.

LEITE, José Rubens Morato e AYALA, Patrick de Araújo. Dano ambiental: do individual ao cole tivo extrapatrimonial. São Paulo: Revista dos Tribunais, 2011.

LEMOS, Patrícia FagaIglecias. Direito Ambiental: Responsabilidade Civil e prote ção ao meio ambiente.3, ed. rev., atual. eampl. São Paulo: Editora Revista dos Tribunais, 2010.

MACHADO, Paulo Affonso Leme. Direito Ambiental B rasileiro. 23. ed. rev., atual. eampl. São Paulo: Malheiros Editores, 2015.

. Estudos de Direito Ambiental. São Paulo: Malheiros Editores, 1994.

MIRAGEM, Bruno. O artigo 1.228 do Código Civil e os de veres do proprie tário em maté ria de preservação do meio ambiente. Disponível em $<$ http://www.egov.ufsc.br/porta//sites/default/files/anexos/26833-26835-1-PB.pdf>. Acesso em: 12 out. 15 .

PADILHA, Norma Sueli. Fundamentos Constitucionais do Direito Ambiental B rasileiro. Rio de Janeiro: Elsevier 2010.

PELLERINO, Giovanni. Evolução do Conceito de Propriedade: "Da Função Social" à "Função Estrutural". Tradução: Maria Lúcia Karam. Revista Veredas do Direito. v.2. n. 3. Belo Horizonte. Janeiro/Dezembro 2005. p. 33-46.

REZENDE, ElcioNacur; GONÇALVES, Daniela Oliveira. Função Socioambiental da propriedade: a busca por uma determinação pragmática de aferição de cumprimento. Revista Paradigma. v. 22. Ribeirão Preto. Janeiro/Dezembro 2013, p. 119-140.

ROSA, Mardióli Dalla. Dano ambiental ocasionado pela exploração desenfreada dos recursos ambientais. Revista Vere das do Direito. v. 7. n. 13/14. Belo Horizonte. Janeiro/Dezembro 2010. p. 157-172.

ROSENVALD, Nelson. As funções da Responsabilidade Civil: a reparação e a pe na civil. São Paulo: Altas, 2013.

SANDEL, Michael. Justiça: o que é fazer a coisa certa. Tradução: Heloisa Matias e Maria Alice Máximo. 4. ed. Rio de Janeiro: Civilização Brasileira, 2011. 
SARLET, Info Wolfgang; FENSTERSEIFER, Tiago. Dire ito Cons titucional ambie ntal: Constituição, direitos fundamentais e proteção do ambiente. 2.ed. rev. e atual. - São Paulo: Editora Revista dos Tribunais, 2012.

SILVA, José Afonso da. Direito Ambiental Constitucional. 6.ed. São Paulo: Malheiros Editores, 2007.

SUPREMO TRIBUNAL FEDERAL -MS nº 22.164-0, j. 30.10.1995, DJU 17.11.1995. Disponível em: http//www.stf.jus.br/portal/juris prudencia/listarJurisprudencia.asp?s1=\%28MS\%24\%2ESCL $\mathrm{A} \% 2 \mathrm{E}+\mathrm{E}+22164 \% 2 \mathrm{ENUME} \% 2 \mathrm{E} \% 29+\mathrm{OU}+\% 28 \mathrm{MS} \%$ 2EACMS\% 2E+ADJ2+22164\% 2EAC MS\%2E\%29\&base=baseAcordaos\&url=http://tinyurl.com/afuob5c. Acesso em: 12 out.2015.

VALADÃO, Maristela Aparecida de Oliveira; ARAÚJO, Paula Santos. A (dis)função socioambiental da propriedade no novo Código Florestal brasileiro: uma análise à luz da órbita econômica constitucional. Revista Dire ito Ambiental e Sociedade. v.3. n. 1. 2013. p.139-172. 